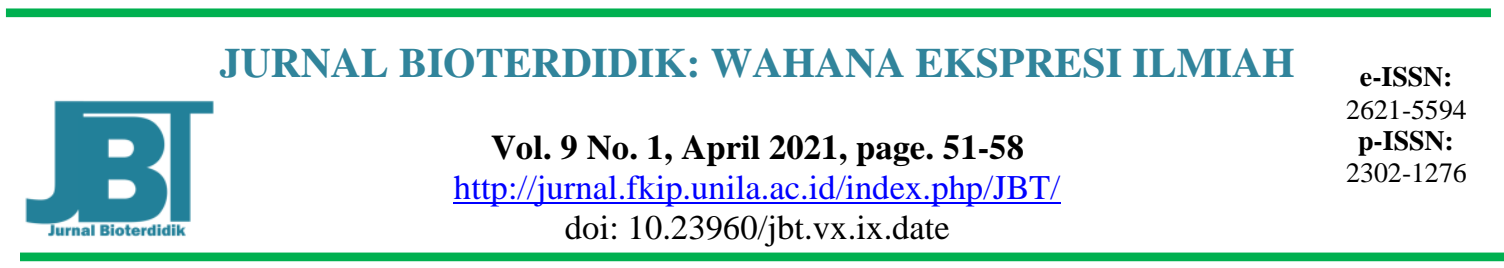

\title{
Hubungan Konsep Diri dengan Kemampuan Berpikir Kritis Peserta Didik Konsep Ekosistem
}

\author{
Nurhasah, Diana Hernawati, Ryan Ardiansyah \\ Pendidikan Biologi, Universitas Siliwangi, J1. Siliwangi No.24, Kahuripan, Kec. Tawang, \\ Tasikmalaya, Jawa Barat, Indonesia \\ *email: nurh83781@gmail.com
}

\begin{abstract}
Relation Between Students' Self Concepts and Critical Thinking Skills on the Ecosystem Material. This research is a correlational study that connects the concepts of self with the learners critical thinking ability on the ecosystem material. Samples of the research of 30 students as participants with sampling techniques purposive sampled. The research instruments used include questionnaires adopted from the Tennessee Self Concept Scale (TSCS) developed by William H. Fitts and a breakdown test for measuring critical thinking skills. The self-concept questionnaire consisted of 43 statements. Hypotheses testing uses bivariate correlation regression. Before a hypothesis test with a regression linierity is performed, first data is tested for normality and its homogenization as a prerequisite test analysis. The results showed no relation between self-concept and critical thinking ability $(R=0,471 ; R 2=0,222)$ means there is a self-concept contribution to the critical thinking ability of $22.2 \%$.
\end{abstract}

Keywords: critical thinking ability, learners, self concept

\begin{abstract}
Abstrak: Hubungan Konsep Diri dengan Kemampuan Berpikir Kritis Peserta Didik pada Materi Ekosistem. Penelitian ini merupakan penelitian korelasional yang menghubungkan antara konsep diri dengan kemampuan berpikir kritis peserta didik pada materi ekosistem. Sampel penelitian sebanyak 30 peserta didik sebagai partisipan dengan teknik pengambilan sampel secara purposive sampling. Instrumen penelitian yang digunakan meliputi kuesioner yang diadopsi dari Tennessee Self Concept Scale (TSCS) yang dikembangkan oleh William $\mathrm{H}$. Fitts dan tes uraian untuk mengukur kemampuan berpikir kritis. Pengujian hipotesis menggunakan regresi korelasi bivariat. Sebelum uji hipotesis dengan linieritas regresi dilakukan, terlebih dahulu data diuji normalitas dan homogenitasnya sebagai uji prasyarat analisis. Hasil penelitian menunjukkan ada hubungan antara konsep diri dengan kemampuan berpikir kritis $(\mathrm{R}=0,471 ; \mathrm{R} 2=0,222)$ artinya terdapat kontribusi konsep diri terhadap kemampuan berpikir kritis sebesar $22,2 \%$.
\end{abstract}

Kata kunci: kemampuan berpikir kritis, konsep diri, peserta didik 


\section{PENDAHULUAN}

Konsep diri merupakan suatu hal yang diperlukan dalam menghadapi permasalahan atau tugas. Konsep diri dapat didefinisikan sebagai cara individu berpikir, merasa, bertindak, menilai dan mengevaluasi dirinya sendiri (Barus, Restuati, \& Gultom, 2018). Konsep diri individu ada yang positif atau negatif. Menurut (Haryanti, Rahmi, \& Syamsi, 2016) konsep diri yang positif akan menentukan tingkah laku seseorang untuk menempatkan diri sesuai dengan gambaran yang peserta didik buat tentang dirinya. Dalam perilaku belajar, konsep diri positif mendorong seseorang untuk mengenal siapa dirinya dan apa yang dilakukannya sebagai peserta didik. Sebaliknya, konsep diri negatif menggambarkan dirinya bahwa memiliki kekurangan atau tingkah laku yang kurang baik. Peserta didik yang memiliki konsep diri negatif akan terlihat pesimis, merasa tidak disenangi, tidak diperhatikan, dan tidak percaya diri.

Konsep diri merupakan pilar utama dalam keberhasilan proses pembelajaran (Junaeti, Sutarno, \& Nurmalasari, 2018). Di dalam proses pembelajaran pendidik memberi dorongan, semangat atau pun motivasi belajar. Pendidik perlu menciptakan situasi pembelajaran yang dapat mengembangkan konsep diri positif dan menghindari konsep diri yang negatif pada peserta didik. Pada proses pembelajaran peserta didik akan mengembangkan kemampuan yang dimilikinya. (Ahmad, 2015) menyatakan bahwa kemampuan pemahaman diri dan kemampuan berpikir kritis yang sudah dimiliki oleh setiap individu merupakan anugerah yang telah diberikan maka harus dipergunakan dan dikembangkan ke arah yang lebih baik. Di dalam proses pembelajaran dapat melatih kemampuan berpikir kritis peserta didik.

Kemampuan berpikir kritis merupakan kemampuan yang sangat esensial dan berfungsi efektif dalam semua aspek kehidupan. Kemampuan berpikir kritis sebaiknya ditanamkan sejak dini baik di sekolah, keluarga maupun di lingkungan masyarakat. Sisworo \& Dkk, (2016) menyatakan bahwa kemampuan berpikir kritis sangat penting dikuasi oleh peserta didik agar lebih terampil dalam menyusun sebuah argumen, memeriksa kredibilitas sumber, atau membuat keputusan. Namun kenyataannya, kemampuan berpikir kritis peserta didik masih relatif rendah. Hal itu diketahui berdasarkan hasil programne for international student assessment (OECD, 2014), skor literasi Indonesia adalah 382 dengan peringkat 64 dari 65 negara. Soal yang digunakan terdiri atas 6 level (level 1 terendah dan level 6 tertinggi). Peserta didik di Indonesia hanya mampu menjawab pada level 1 dan level 2. Untuk itu kemampuan berpikir kritis peserta didik perlu dikembangkan dalam pembelajaran maupun kehidupan sehari-hari.

Pembelajaran biologi sebagai bagian dari sains memiliki sasaran dari pembelajaran yaitu proses, produk, dan sikap. Selain itu pembelajaran sains juga mempunyai karakteristik tentatif dan dinamis sehingga menuntut peserta didik untuk selalu berpikir kritis dalam mempelajarinya (Rohani, 2013). Pada pembelajaran biologi terdapat materi yang di dalamnya menyangkut pemasalahan dalam kehidupan sehari-hari, seperti materi ekosistem. Materi ekosistem umumnya mudah dipahami karena dapat dikaitkan dengan permasalahan kehidupan sehari-hari. Namun, masih banyak peserta didik yang mengalami kegagalan dalam pembelajaran bukan disebabkan oleh tingkat intelektual yang rendah atau kemampuan fisik yang lemah, melainkan oleh adanya perasaan tidak mampu untuk melakukan tugas (Dhatu dan Ediati, 2015).

Hasil penelitian yang dilakukan (Antler, 2015) menjelaskan bahwa nilai total konsep diri signifikan dan positif berhubungan dengan nilai total berpikir kritis. Analisis regresi nya menunjukkan konsep diri adalah sebuah prediksi yang lebih baik dari berpikir kritis daripada metakognisi dan keterbukaan pada pengalaman. Hasil penelitiannya 
menyarankan bahwa makanan bergizi dapat mendukung konsep diri untuk kemampuan berpikir kritis. Barus et al., (2018) dalam penelitiannya menunjukkan hubungan yang positif antara konsep diri dengan kemampuan berpikir kritis peserta didik pada program lintas minat biologi.

Ketika peserta didik memiliki konsep diri yang positif mereka akan berani bertanggungjawab terhadap apa yang dilakukannya, mandiri, meyakini bahwa keberhasilan maupun kegagalan tergantung dari apa yang telah diusahakan dan memiliki cita-cita. Namun ketika peserta didik memiliki konsep diri yang negatif mereka akan takut kegagalan, tidak berani mengambil risiko, motivasi belajar dan bekerja yang rendah, juga kurang berani mengambil risiko terhadap tindakan yang dilakukan (Subaryana, 2015). Untuk itu penting dilakukan penelitian lebih lanjut mengenai hubungan konsep diri dengan kemampuan berpikir kritis pada siswa biologi.

\section{METODE}

Penelitian ini menggunakan metode korelasional sederhana atau biasa dikenal bivariate correlation (Creswell, 2013). Sampel penelitian diambil secara purposive sampling sebanyak 30 orang peserta didik kelas X MIPA. Tempat penelitian dilakukan di salah satu SMA Negeri Kota Tasikmalaya pada bulan Mei-Juni 2020.

Instrumen yang digunakan dalam penelitian ini meliputi instrumen untuk mengukur konsep diri dengan menggunakan kuesioner yang diadopsi dari Tennessee Self-Concept Scale (TSCS) dan dikembangkan oleh Fitts (1971). Kuesioner konsep diri terdiri dari 43 pernyataan. Setiap item memiliki alternatif jawaban yang menunjukkan derajat kesesuaian atau ketidaksesuaian dengan diri subjek. Alternatif jawaban terdiri dari 5 pilihan, yaitu sangat sesuai (SS), sesuai (S), tidak pasti (TP), tidak sesuai (TS), dan sangat tidak sesuai (STS). Sementara kemampuan berpikir kritis peserta didik di ukur menggunakan soal uraian materi ekosistem terdiri dari 15 soal yang indikatornya dari Ennis (1993). Pengujian hipotesis menggunakan regresi korelasi bivariat. Sebelum uji hipotesis dengan linieritas regresi dilakukan, terlebih dahulu data diuji normalitas dan homogenitasnya sebagai uji prasyarat analisis.

\section{HASIL DAN PEMBAHASAN}

Berdasarkan hasil analisis uji regresi korelasi dengan menggunakan SPSS versi 25 diperoleh hasil pada Tabel 1.

Tabel 1. Hasil Regresi Korelasi Bivariat

\begin{tabular}{|c|c|c|c|c|c|c|c|c|c|}
\hline \multirow[b]{2}{*}{$\begin{array}{l}\text { Mod } \\
\text { el }\end{array}$} & \multirow[b]{2}{*}{$\mathbf{R}$} & \multirow[b]{2}{*}{$\begin{array}{c}\mathbf{R} \\
\text { Square }\end{array}$} & \multirow[b]{2}{*}{$\begin{array}{l}\text { Adjusted } \\
\text { R Square }\end{array}$} & \multirow{2}{*}{$\begin{array}{c}\text { Std. } \\
\text { Error of } \\
\text { the } \\
\text { Estimate }\end{array}$} & \multicolumn{5}{|c|}{ Change Statistics } \\
\hline & & & & & $\begin{array}{c}\text { R Square } \\
\text { Change }\end{array}$ & $\begin{array}{c}F \\
\text { Change }\end{array}$ & df1 & df 2 & $\begin{array}{c}\text { Sig. F } \\
\text { Change }\end{array}$ \\
\hline 1 & $.471^{\mathrm{a}}$ & .222 & .194 & 4.833 & .222 & 7.977 & 1 & 28 & .009 \\
\hline
\end{tabular}

Tabel 1 menjelaskan nilai signifikansi sebesar 0,009 dengan taraf signifikansi 0,05. Nilai signifikansi $<0,05$ sehingga hipotesisnya Tolak Ho yang berarti ada korelasi antara konsep diri dengan kemampuan berpikir kritis peserta didik pada materi ekosistem secara signifikan. Korelasi antara konsep diri dengan kemampuan berpikir kritis pada materi ekosistem memiliki nilai koefisien korelasi (R) sebesar 0,471 yang berarti hubungan antara variabel bersifat sedang. Untuk nilai koefisien determinasi (R2) sebesar 0,222 atau 
22,2\%. Hal ini menunjukkan bahwa variabel konsep diri memberikan kontribusi sebesar $22,2 \%$ terhadap kemampuan berpikir kritis peserta didik sedangkan sisanya $77,8 \%$ merupakan pengaruh variabel lain yang tidak diteliti dalam penelitian ini.

Hasil korelasi antara konsep diri dengan kemampuan berpikir kritis ditunjukkan dengan grafik scatterplot (bivar) $=\mathrm{X}$ dengan Y pada Gambar 1.

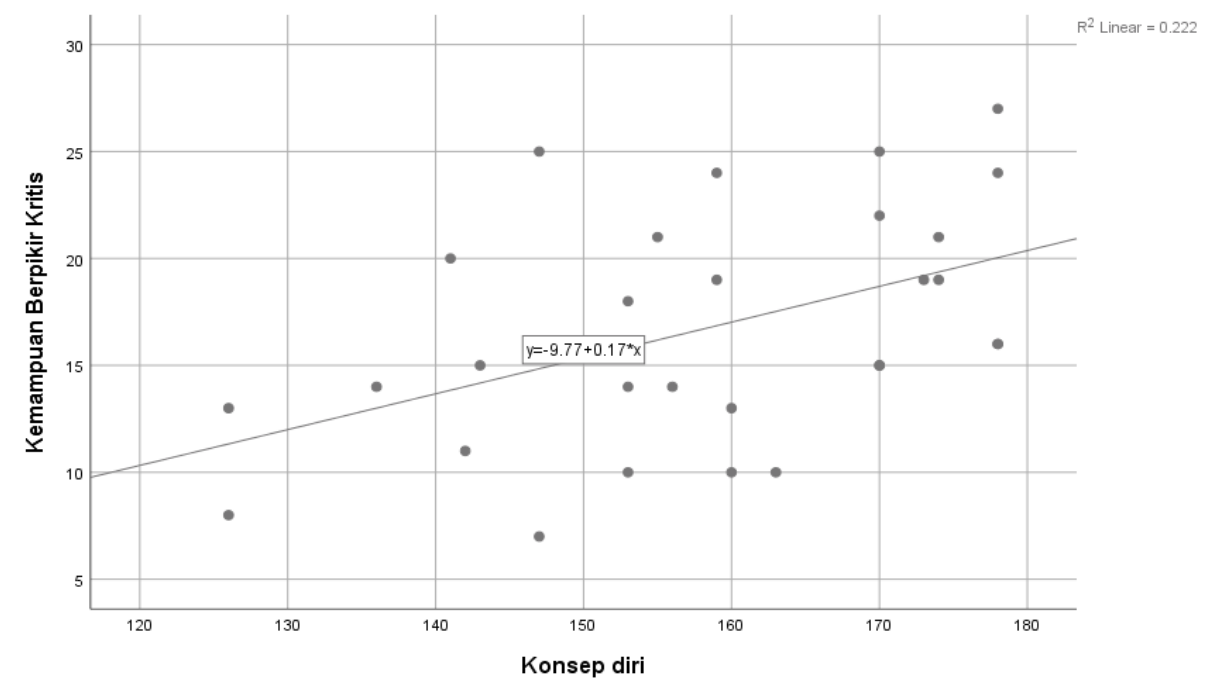

Gambar 1. Grafik Scatterplot (Bivar) $=$ X dengan Y

Grafik scatterplot pada Gambar 1, menjelaskan pola garis linearitas antara konsep diri dengan kemampuan berpikir kritis peserta didik. Sementara titik-titik pada plot menunjukkan besarnya penyimpangan (error) dari hubungan tersebut. Hubungan positif ini dapat bermakna bahwa jika konsep diri peserta didik mengalami peningkatan maka kemampuan berpikir kritis akan meningkat pula. Persamaan regresi dalam penelitian ini yaitu $Y=a+b x$. Hasil analisis regresi diperoleh koefisien untuk variabel konsep diri sebesar 0,167 dengan konstanta (a) sebesar $-9,770$ sehingga persamaan regresi yang

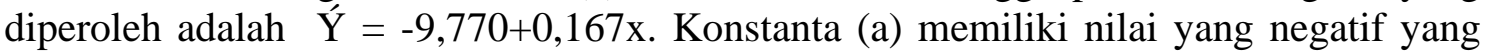
berarti jika skor variabel konsep diri dianggap tidak ada atau sama dengan nol, maka skor kemampuan berpikir kritis akan semakin berkurang. Apabila konsep diri ditingkatkan sebesar satu kali maka kemampuan berpikir kritis peserta didik akan meningkat sebesar 0,167 .

Pada penelitian ini untuk mengetahui konsep diri yang positif (tinggi), peneliti mengelompokkan data tingkat konsep diri peserta didik ke dalam tiga kategori yaitu tinggi, sedang, dan rendah. Tujuan pengkategorian ini untuk menempatkan individu ke dalam kelompok-kelompok yang terpisah secara berjenjang. Menurut suatu kontinum berdasarkan atribut yang diukur. Dalam membuat kategorisasi diperlukan mean teoretik dan satuan standar deviasi populasi. Standar deviasi dihitung dengan cara mencari rentang skor, yaitu skor maksimal dikurangi dengan skor minimal, kemudian rentang skor tersebut dibagi enam (Azwar, 2012) Hasil pengkategorian konsep diri dapat dilihat pada Gambar 2. 


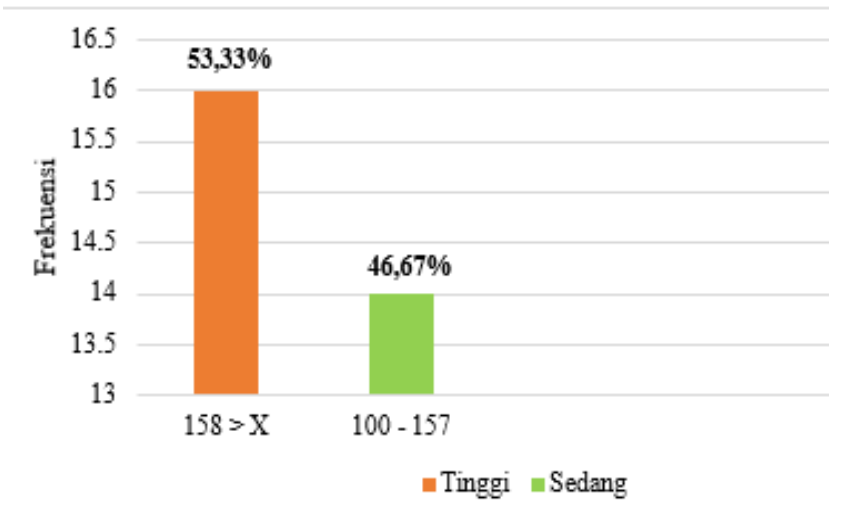

Gambar 2. Diagram Kategorisasi Konsep Diri

Berdasarkan hasil kategorisasi konsep diri, peserta didik yang memiliki konsep diri tinggi sebesar 53,33\%. Peserta didik yang memiliki konsep diri tinggi dapat menyelesaikan permasalahan yang diberikan seperti pada tes kemampuan berpikir kritis. Sejalan dengan pernyataan tersebut, Folastri \& Prasetyaningtyas, (2017) menjelaskan bahwa peserta didik yang mempunyai konsep diri yang tinggi akan menggunakan segala potensi dan kemampuannya seoptimal mungkin dengan jalan mengikuti proses pembelajaran dengan baik. Peserta didik dengan konsep diri tinggi akan terlihat optimis, penuh percaya diri dan selalu bersikap positif terhadap segala sesuatu. Novilita \& Suharnan, (2013) berpendapat bahwa peserta didik dengan konsep diri yang tinggi akan cenderung memiliki tingkat kemandirian dalam belajar yang tinggi. Sebaliknya peserta didik dengan konsep diri yang rendah akan cenderung memiliki tingkat kemandirian dalam belajar yang rendah pula.

Apabila seseorang individu pembelajar mampu mengonsep dirinya atas permasalahan yang dihadapi dampak secara tidak langsung dapat berpikir secara kritis (Ahmad, 2015). Konsep diri yang tinggi sangat berpengaruh dalam pembelajaran, ketika peserta didik memiliki konsep diri yang tinggi maka dapat menyelesaikan permasalahan dengan baik. Noviyanti, Rusdi, \& Ristanto, (2019) menyatakan bahwa kelompok peserta didik yang memiliki konsep diri tinggi dengan kelompok yang memiliki konsep diri rendah, memiliki nilai rata-rata keterampilan berpikir kritis lebih tinggi daripada kelompok peserta didik yang memiliki konsep diri rendah.

Peserta didik yang masuk ke dalam kategori sedang sebesar 46,67\%, dalam penelitian ini tidak ada peserta didik yang masuk ke dalam kategori rendah. Konsep diri yang sedang dan rendah diartikan sebagai konsep diri yang cenderung belum ideal atau tidak diharapkan. Hal tersebut dikarenakan peserta didik belum mampu menerima, mencintai, dan menghargai dirinya sendiri. Peserta didik yang memiliki konsep diri sedang atau rendah memiliki kecenderungan lebih tertutup dan sulit untuk mengembangkan diri. McInerney (2006) menyatakan bahwa konsep diri adalah salah satu aspek perkembangan psikososial individu yang penting karena sebagai salah satu variabel yang menentukan dalam proses pendidikan.

Peserta didik yang memiliki konsep diri sedang atau pun rendah akan berpengaruh ke proses pembelajaran, jika tidak ada kemauan untuk belajar maka akan sulit mengembangkan kemampuan yang dimilikinya. Folastri \& Prasetyaningtyas (2017) berpendapat bahwa peserta didik yang mempunyai konsep diri sedang dan rendah, akan meyakini dan memandang bahwa dirinya lemah, tidak berkompeten, tidak menggunakan potensi yang dimilikinya secara optimal sehingga menimbulkan perasaan rendah diri, 
merasa ragu, kurang percaya diri dan sengaja mencari perhatian. Peng, Fan, \& Dey, (2011) menyatakan bahwa dalam proses penerapan pembelajaran yang merupakan hambatan utama adalah hambatan psikologis yang malas untuk berpikir dan melihat ketidakmungkinan penemuan. Hambatan itu dapat menyebabkan nilai rata-rata keterampilan berpikir kritis peserta didik dengan konsep diri yang sedang lebih rendah daripada peserta didik yang memiliki konsep diri tinggi.

Selanjutnya untuk tingkat kemampuan berpikir kritis peserta didik, terdapat tiga kategori yaitu tinggi, sedang, dan rendah. Hasil kategorisasi kemampuan berpikir kritis dapat dilihat pada Gambar 3 .

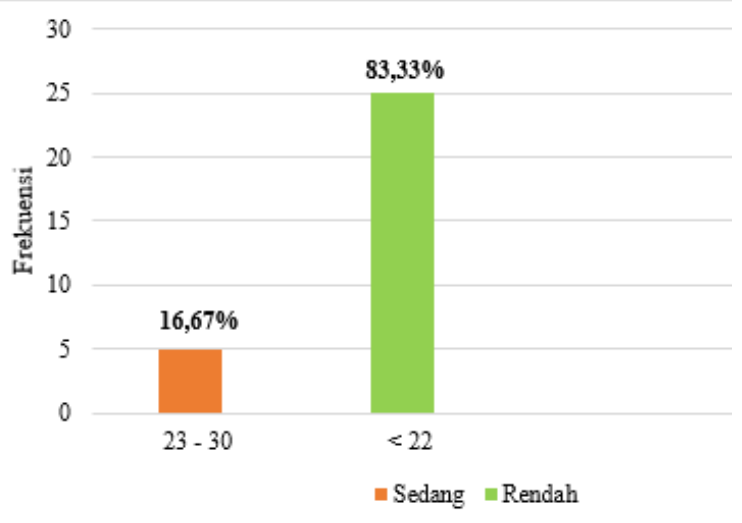

Gambar 3. Diagram Kategorisasi Kemampuan Berpikir Kritis

Hasil penelitian kemampuan berpikir kritis peserta didik sebagian besar menunjukkan pada kategori rendah dengan persentase $83,33 \%$. Karena sebagian besar memiliki kemampuan berpikir kritis rendah, baiknya dalam pembelajaran sering dilatih dengan memberikan soal-soal kemampuan berpikir kritis. Sihotang, (2012) menjelaskan bahwa kemampuan berpikir kritis merupakan faktor intrinsik. Peserta didik yang kritis dalam proses pembelajaran memungkinkan memiliki prestasi belajar yang tinggi karena lebih mudah mengikuti pembelajaran, sedangkan peserta didik yang pasif cenderung lebih sulit mengikuti pembelajaran. Kenyataannya tidak sedikit dijumpai peserta didik berprestasi tinggi namun kurang kritis berpikir. Berpikir kritis dapat dikembangkan dengan memberikan kesempatan kepada peserta didik memecahkan soal dengan metodenya.

Kemampuan berpikir kritis dapat ditingkatkan dengan menerapkan strategi yang memiliki ciri melibatkan interaksi aktif dari peserta didik dan menggunakan kemampuan kognitifnya dalam mengaplikasikan konsep dan memecahkan masalah (Agboeze \& Ugwoke, 2013). Permasalahan yang akan dihadapi oleh peserta didik tidak hanya dalam pembelajaran saja namun dalam kehidupan sehari-hari pun banyak permasalahan yang akan dihadapi peserta didik sehingga peserta didik dituntut untuk memiliki kemampuan berpikir kritis agar dapat membuat suatu keputusan atau tindakan yang tepat dalam memecahkan setiap permasalahan yang dihadapi (Meriyana, R., Suprapto, P. K., \& Hernawati, D. 2020; Muhamad, Falah, \& Windyariani, 2018).

Kemampuan berpikir kritis adalah modal penting bagi setiap individu. Maka penting untuk meningkatkan kemampuan berpikir kritis dalam pembelajaran. Banyak hal yang dapat meningkatkan kemampuan berpikir kritis peserta didik dalam pembelajaran, diantaranya dengan meningkatkan konsep diri peserta didik. Guru hendaknya selalu membimbing peserta didik agar memiliki konsep diri yang tinggi. Barus et al., (2018) 
menjelaskan bahwa peserta didik yang memiliki konsep diri tinggi akan menyelesaikan tugas atau permasalahan yang diberikan. Dengan demikian, peserta didik mampu meningkatkan kualitas atau kemampuan yang ada pada dirinya seperti kemampuan berpikir kritis. Peserta didik juga harus mengerti dan memahami apa kelebihan dan kekurangan dalam dirinya sendiri sehingga diharapkan tumbuh konsep diri tinggi dalam diri peserta didik guna meningkatkan kemampuan berpikir kritis pada pelajaran biologi secara maksimal.

Peserta didik yang memiliki konsep diri rendah akan menyebabkan keterampilan berpikir menjadi lemah. Untuk menjelaskan suatu konsep, serta menghubungkan konsep menjadi suatu pemahaman yang baru kurang baik meskipun bisa dilakukan tetapi dalam proses berpikirnya menjadi lambat. Membuat peserta didik sulit untuk mengolah konsep pengetahuan yang mereka peroleh untuk menjadi suatu pengetahuan baru dalam hal kemampuan menelaah, menalar yang tidak maksimal (Magfirah, Rahman, \& Sulasteri, 2015)

\section{SIMPULAN}

Berdasarkan hasil penelitian dapat disimpulkan bahwa terdapat hubungan positif antara konsep diri dengan kemampuan berpikir kritis peserta didik pada materi ekosistem. Nilai koefisien korelasi (R) sebesar 0,471 yang berarti hubungan antar variabel bersifat sedang. Untuk nilai koefisien determinasi (R2) sebesar 0,222 atau 22,2\%. Hal ini menunjukkan bahwa variabel konsep diri memberikan kontribusi sebesar 22,2\% terhadap kemampuan berpikir kritis peserta didik.

\section{DAFTAR RUJUKAN}

Agboeze, M. U., \& Ugwoke, E. O. (2013). Enhancement of Critical Thinking Skills of Vocational and Adult Education Students for Entrepreneurship Development in Nigeria. Journal of Education.

Ahmad, D. N. (2015). Pengaruh Kemampuan Berpikir Kritik dan Konsep Diri terhadap Prestasi Belajar IPA. Formatif: Jurnal Ilmiah Pendidikan MIPA. https://doi.org/10.30998/formatif.v5i1.162

Antler, M. (2015). I am a critical thinker : exploring the relationship between self-concept and critical thinking ability, (2013).

Azwar, S. (2012). Penyusunan skala psikologi (ed.2). Pustaka Pelajar.

Barus, E. M., Restuati, M., \& Gultom, T. (2018). Hubungan Konsep Diri Dengan Kemampuan Berpikir Kritis Siswa Kelas X Mia Pada Mata Pelajaran Biologi Program Lintas Minat. Jurnal Ilmiah Farmasi Imelda.

Creswell, J. W. (2013). Educational Research: Planning, Conducting, and Evaluating Quantitative and Qualitative Research. Journal of Chemical Information and Modeling. https://doi.org/10.1017/CBO9781107415324.004

Dhatu, Okky Mega dan Ediati. (2015). Konsep Diri Akademik Dan Motivasi Berprestasi Pada Siswa Smp N 24 Purworejo. (2015). Empati: Jurnal Karya Ilmiah S1 Undip.

Ennis, R. H. (1993). Critical thinking assessment. Theory Into Practice. https://doi.org/10.1080/00405849309543594

Fitts, W. H. (1971). The self-concept and self-actualization. Studies on the Self Concept.

Folastri, S., \& Prasetyaningtyas, W. E. (2017). Gambaran konsep diri siswa di sekolah menengah kejuruan sumbangsih Jakarta Selatan. TERAPUTIK: Jurnal Bimbingan Dan Konseling. https://doi.org/10.26539/118

Haryanti, H., Rahmi, R., \& Syamsi, F. (2016). Hubungan Konsep Diri Dengan Hasil 
Belajar Biologi Siswa Kelas Vii Mts Unit Sekolah Baru (Usb) Sagulung Batam. SIMBIOSA. https://doi.org/10.33373/sim-bio.v5i2.816

Junaeti, E., Sutarno, H., \& Nurmalasari, R. R. (2018). Genius Learning Strategy of Basic Programming in an Adventure Game. In IOP Conference Series: Materials Science and Engineering. https://doi.org/10.1088/1757-899X/288/1/012057

Magfirah, I., Rahman, U., \& Sulasteri, S. (2015). Pengaruh Konsep Diri Dan Kebiasaan Belajar Terhadap Hasil Belajar Matematika Siswa Kelas VIII SMP Negeri 6 Bontomatene Kepulauan Selayar. Jurnal Matematika Dan Pembelajaran.

McInerney, D. M. (2006). Development Psychology For Teacher. Australia: National Library.

Meriyana, R., Suprapto, P. K., \& Hernawati, D. (2020). Efektivitas Model Discovery Learning Terhadap Kemampuan Berpikir Kritis Peserta Didik Pada Sub Konsep Bryophyta Dan Pteridophyta Di Kelas X Sma It Riyadlussholihin Sukaratu. Jurnal METAEDUKASI, 2(2), 64-78.

Muhamad, C., Falah, N., \& Windyariani, S. (2018). Peningkatan Kemampuan Berpikir Kritis Peserta Didik Melalui Model Pembelajaran Search, Solve, Create, and Share (SSCS) Berbasis Etnosains. Didaktika Biologi, 2, 25-32.

Novilita, H., \& Suharnan, S. (2013). Konsep Diri Adversity Quotient Dan Kemandirian Belajar Siswa. Jurnal Psikologi Tabularasa.

Noviyanti, E., Rusdi, R., \& Ristanto, R. H. (2019). Guided Discovery Learning Based on Internet and Self Concept: Enhancing Student's Critical Thinking in Biology. Indonesian Journal of Biology Education. https://doi.org/10.31002/ijobe.v2i1.1196

OECD. (2014). PISA 2012 results: What students know and can do-Student Performance in Mathematics, Reading and Science. OECD Publishing. https://doi.org/10.1037/e530172011-002

Peng, G., Fan, M., \& Dey, D. (2011). Impact of network effects and diffusion channels on home computer adoption. Decision Support Systems. https://doi.org/10.1016/j.dss.2011.01.004

Rohani. (2013). Correlation Between Science Process Skill and Student Critical Thinking Through Inquiry Learning Strategy on Environment Pollution At Sma Negeri 3 Palangkaraya. EduSains, 1(2), 1-10.

Sihotang, H. (2012). Pengaruh Konsep Diri Dan Berpikir Kritis Terhadap Prestasi Belajar Matematika Siswa Smp Se- Jakarta Timur. Jurnal Dinamika Pendidikan.

Sisworo, \& Dkk. (2016). Analisis Kemampuan Berpikir Kritis. Prosiding Konferensi Nasional Penelitian Matematika Dan Pembelajarannya. https://doi.org/10.23971/eds.v5i2.732

Subaryana. (2015). Konsep diri dan prestasi belajar. Jurnal Dinamika Pendidikan Dasar. 